\title{
Demonstration of antiglobulin activity in the synovial membrane of patients with rheumatoid arthritis and ankylosing spondylitis after pepsin treatment: real or artefact?
}

\author{
P G DAVIES, ${ }^{1}$ P A REVELL , 2 AND V MAYSTON ${ }^{2}$ \\ From the 'Chelmsford \& Essex Hospital, Chelmsford, Essex; and the ${ }^{2}$ Bone and Joint Research Unit and \\ Department of Morbid Anatomy, The London Hospital Medical College, London
}

SUMmaRY The results of immunofluorescence studies in nine cases of rheumatoid arthritis and nine cases of ankylosing spondylitis are presented. Antiglobulin activity was sought with fluorescein labelled, heat aggregated human $\mathrm{IgG}$ and rabbit immunoglobulin (indirect immunofluorescence). A similar degree of increased staining for rheumatoid factor activity was seen after pepsin digestion in all cases of rheumatoid arthritis and three of the ankylosing spondylitic cases. This staining for rheumatoid factor could also be shown in control tissue after pepsin digestion, suggesting that the enhanced staining was an artefact.

Key words: immunofluorescence, joints, rheumatoid factor.

The synovial membrane in chronic inflammatory joint disease shows an infiltrate in which lymphocytes and plasma cells predominate, frequently with the formation of lymphoid follicles.

Immunofluorescent studies of synovium in rheumatoid arthritis (RA) have been performed by various workers and the presence of rheumatoid factor (antiglobulin activity) demonstrated. ${ }^{1-19}$ Mellors et al were the first to show IgM rheumatoid factor activity in the plasma cells of seropositive RA synovia using fluorescein labelled, heat aggregated IgG. ${ }^{2}$ Munthe and Natvig confirmed Mellors' observations and found little or no binding of heat aggregated IgG to the plasma cells containing predominantly IgG in RA synovia. ${ }^{16}$ After pepsin digestion of the tissue sections, however, binding of heat aggregated IgG was increased to between $30 \%$ and $60 \%$ of plasma cells in both seronegative and seropositive cases, representing 'hidden' IgG rheumatoid factor activity. The proposed mechanism for this enhancement was considered to be digestion of the Fc portions of self associated IgG rheumatoid factors leading to the release of the Fab sites.

Accepted for publication 9 April 1986.

Correspondence to Dr P G Davies. Chelmsford \& Essex Hospital. Chelmsford. Essex CM2 0QH.
Few further published reports on this finding of 'hidden' rheumatoid factor activity have been published. There have been no formal studies using immunofluorescent staining of the synovial membrane in ankylosing spondylitis (AS) save Fehr et al who reported a single case of AS in which immunofluorescent studies failed to show any IgG, IgM or rheumatoid factor staining. ${ }^{19}$ We decided, therefore, to investigate the possible differences between synovia from cases of RA and AS with the pepsin digestion technique.

\section{Materials and methods}

SYNOVIAL TISSUE

Samples of synovial tissue were obtained at the time of joint surgery from nine patients with AS and from nine patients with RA. Four of the AS patients were juvenile in onset, and eight of the RA patients were seropositive, while one was seronegative. Brief clinical details are shown in Table 1 .

TONSILLAR TISSUE

Control tissue was obtained at the time of tonsillectomy from three patients.

MYELOMA MARROW CELLS

Bone marrow aspirate was obtained from single 
Table 1 Patient details

\begin{tabular}{|c|c|c|c|c|c|}
\hline $\begin{array}{l}\text { Patient } \\
\text { No }\end{array}$ & Sex & $\begin{array}{l}\text { Age at } \\
\text { op/biopsy }\end{array}$ & Diagnosis & $\begin{array}{l}\text { Tissue } \\
\text { origin }\end{array}$ & $\begin{array}{l}\text { Disease } \\
\text { duration } \\
\text { (years) }\end{array}$ \\
\hline 1 & $\mathbf{F}$ & 55 & $\begin{array}{l}\text { Sero }(+) \\
\text { crosive } \\
\text { nodular RA }\end{array}$ & Knee & 10 \\
\hline 2 & $\mathbf{F}$ & 65 & $\begin{array}{l}\text { Sero (+) } \\
\text { erosive RA }\end{array}$ & Wrist & 15 \\
\hline 3 & $\mathbf{F}$ & 51 & Sero (+) RA & Knee & 11 \\
\hline 4 & $\mathbf{M}$ & 58 & Sero (+) RA & Knee & 20 \\
\hline 5 & $\mathbf{M}$ & 49 & $\begin{array}{l}\text { Sero (+) } \\
\text { erosive } \\
\text { anodular RA }\end{array}$ & $\begin{array}{l}\text { Right } \\
\text { knee }\end{array}$ & 17 \\
\hline 6 & $\mathbf{M}$ & 49 & $\begin{array}{l}\text { Sero }(+) \\
\text { erosive } \\
\text { anodular RA }\end{array}$ & $\begin{array}{l}\text { Left } \\
\text { knee }\end{array}$ & 17 \\
\hline 7 & $\mathbf{F}$ & 59 & $\begin{array}{l}\text { Sero }(+) \\
\text { erosive RA }\end{array}$ & Wrist & 8 \\
\hline 8 & $\mathbf{F}$ & 55 & $\begin{array}{l}\text { Sero }(+) \\
\text { erosive } \\
\text { anodular RA }\end{array}$ & Knee & 19 \\
\hline 9 & $\mathbf{M}$ & 63 & $\begin{array}{l}\text { Sero }(-) \\
\text { erosive } \\
\text { anodular RA }\end{array}$ & Knee & 9 \\
\hline 10 & $\mathbf{M}$ & 41 & AS & Hip & 24 \\
\hline 11 & $\mathbf{M}$ & 30 & AS & Hip & 10 \\
\hline 12 & $\mathbf{M}$ & 16 & AS & Hip & 4 \\
\hline 13 & $\mathbf{M}$ & 16 & AS & Hip & 4 \\
\hline 14 & $\mathbf{M}$ & 27 & AS & Hip & 11 \\
\hline 15 & $\mathbf{M}$ & 13 & AS $\left(B 27^{+}\right)$ & MCP* & 2 \\
\hline 16 & F & 25 & $\mathrm{AS}\left(\mathrm{B} 27^{+}\right)$ & Hip & 11 \\
\hline 17 & $\mathbf{M}$ & 34 & AS & Hip & 24 \\
\hline 18 & $\mathbf{M}$ & 19 & AS $\left(B 27^{+}\right)$ & Hip & $\mathrm{NK}^{*}$ \\
\hline
\end{tabular}

${ }^{*} \mathrm{MCP}=$ metacarpophalangeal joint; $\mathrm{NK}=$ not known.

cases of IgG and IgA myeloma. A sample of serum was taken at the same time and the presence of rheumatoid factor sought with an enzyme linked immunosorbent assay (ELISA). ${ }^{20}$ The red cells in the marrow aspirate were lysed in $0.83 \%$ ammonium chloride and the white cells pelleted for fixation and processing.

MONOCLONAL TISSUE CULTURE CELLS Two monoclonal tissue culture human cell lines (L4 and KR4) were used. L4 and KR4 are B cell lines producing IgE and IgG respectively, which are known through ELISA studies not to produce rheumatoid factor. These tissue culture cells were lightly spun down for fixation and processing.

HISTOLOGICAL PROCESSING AND STAINING METHODS

All the tissue specimens and the cell pellets were fixed in cold ethanol and embedded in paraffin wax according to the method described by SainteMarie. ${ }^{21}$ Immunofluorescence studies were performed on freshly cut $5 \mu \mathrm{m}$ thick sections.
Immunoglobulin classes in plasma cells were demonstrated by the use of monospecific fluorescein labelled sheep antisera against human IgG, IgM, and IgA (Wellcome Reagents Ltd). Double labelling experiments were performed to establish the immunoglobulin class of the rheumatoid factor activity, using monospecific rhodamine labelled rabbit antisera to human IgG, IgM, and $\operatorname{IgA}$ (Dakopatts, Mercia Brocades Ltd), followed by fluorescein labelled, heat aggregated human IgG.

Rheumatoid factor activity was detected by fluorescein labelled, heat aggregated human IgG (direct immunofluorescence) and monomeric rabbit immunoglobulin in an indirect immunofluorescence system. The fluorescein labelled, heat aggregated human IgG was prepared by first conjugating human IgG (Kabi AB, Stockholm, Sweden) at a concentration of $10 \mathrm{mg} / \mathrm{ml}$ with fluorescein isothiocyanate by the simplified method of Johnson et $a .^{22}$ The conjugate was then run through a Sephadex G50 column to remove the unconjugated fluorochrome. The labelling ratio was $1 \cdot 2: 1$ as determined by a comparison of the optical densities at $495 \mathrm{~nm}$ and $280 \mathrm{~nm}$. The fluorescein labelled IgG was then heat aggregated at $63^{\circ} \mathrm{C}$ for 10 minutes. The aggregated conjugate was further purified byo adsorption onto human liver homogenate before use. A concentration of $1-2 \mathrm{mg} / \mathrm{ml}$ was used for the immunohistochemical staining.

In the indirect staining system monomeric rabbit IgG (Sigma Chemical Co) was used in a concentration of $2 \mathrm{mg} / \mathrm{ml}$, followed by fluorescein labelled sheep antirabbit immunoglobulin (1:60) (Wellcome Reagents Ltd).

Tissue sections were either stained without previous enzyme treatment or incubated with $0 \cdot 10$ $\mathrm{mg} / \mathrm{ml}$ of pepsin (1:60 000; twice crystallised; Sigma Chemical Co) in $\mathbf{0 . 1} \mathrm{M}$ acetate buffer $\mathrm{pH} 4.0$ for two hours at $37^{\circ} \mathrm{C}$ before staining.

The specificity of the immunohistochemical reaction for rheumatoid factor in the synovia was checked with blocking procedures and by staining control tissues. In the case of fluorescein labelled, heat aggregated $\mathrm{IgG}$ the conjugate was mixed with human serum albumin, unlabelled monomeric human IgG, and unlabelled aggregated human IgG in separate experiments before incubation with the sections of synovium. Rabbit immunoglobulin was substituted for rabbit $\mathrm{Fc}$ and $\mathrm{F}\left(\mathrm{ab}^{\prime}\right)_{2}$ fragments (2 $\mathrm{mg} / \mathrm{ml}$ ) in separate experiments to check the monomeric rabbit immunoglobulin indirect immunofluorescence technique. The specificity of staining was also checked by studying 'control' tissue: human tonsils, myeloma marrow cells, and monoclonal culture cells. 


\section{Results}

IMMUNOGLOBULIN CLASSES PRESENT IN PLASMA CELLS IN RA AND AS SYNOVIAL MEMBRANES

The proportion of plasma cells containing different immunoglobulin classes was studied using fluorescein labelled antisera in adjacent pepsin digested sections of RA and AS synovia. The results are shown in Table 2. Plasma cells containing IgG

Table 2 Immunoglobulin staining

\begin{tabular}{|c|c|c|c|c|}
\hline \multirow{2}{*}{$\begin{array}{l}\text { Patient } \\
\text { No }\end{array}$} & \multirow{2}{*}{ Diagnosis } & \multicolumn{3}{|c|}{ Plasma cells stained (\%) } \\
\hline & & $\begin{array}{l}F_{T I C^{*}} \\
\text { anti- } \\
\lg G\end{array}$ & $\begin{array}{l}\text { FITC } \\
\text { anti- } \\
\text { IgM }\end{array}$ & $\begin{array}{l}\text { FITC } \\
\text { anti- } \\
\operatorname{IgA}\end{array}$ \\
\hline 1 & Sero (+) RA & 70 & $5-10$ & $10-20$ \\
\hline 2 & Sero (+) RA & 60 & $15-20$ & $15-20$ \\
\hline 3 & Sero (+) RA & 80 & 10 & 10 \\
\hline 4 & Sero (+) RA & $80-90$ & $5-10$ & $5-10$ \\
\hline 5 & Sero (+) RA & 70 & 15 & 15 \\
\hline 6 & Sero (+) RA & 70 & 25 & $<5$ \\
\hline 7 & Sero (+) RA & 70 & 10 & $15-20$ \\
\hline 8 & Sero (+) RA & $70-80$ & 15 & $<5$ \\
\hline 9 & Sero (-) RA & 70 & 2 & 30 \\
\hline 10 & AS & 70 & 5 & 25 \\
\hline 11 & AS & 70 & 5 & 25 \\
\hline 12 & AS & 70 & $<5$ & 30 \\
\hline 13 & AS & 75 & $<5$ & 25 \\
\hline 14 & AS & 70 & 5 & 25 \\
\hline 15 & AS & 65 & 5 & 25 \\
\hline 16 & AS & 80 & $<5$ & $<5$ \\
\hline 17 & AS & $N D \div$ & ND & ND \\
\hline 18 & AS & ND & ND & ND \\
\hline
\end{tabular}

${ }^{*} \mathrm{FITC}=$ fluorescein isothiocyanate.

$\dagger N D=$ not done due to insufficient infiltrate. predominated in both RA and AS synovia, being present in the large majority of cells in all cases. The RA synovia showed approximately equal proportions of plasma cells containing IgM and IgA (IgM $<5 \%$ to $25 \%$; IgA $<5 \%$ to $20 \%$ ). In contrast, the AS synovia showed a relative paucity of plasma cells containing IgM (IgM $5 \%$ or less; IgA $25-30 \%$ ).

\section{RHEUMATOID FACTOR ACTIVITY IN \\ PLASMA CELLS BEFORE AND AFTER \\ PEPSIN DIGESTION \\ $R A$ synovia}

Antiglobulin activity was shown in plasma cells by the use of fluorescein labelled, heat aggregated human IgG (direct immunofluorescence) and monomeric rabbit immunoglobulin (indirect immunofluorescence). The results with and without pepsin treatment are shown in Table 3. Each estimation of the percentage of plasma cells containing antiglobulin was repeated on at least two separate occasions.

In the RA synovia the percentage of plasma cells binding fluorescein labelled, heat aggregated human IgG varied between $5 \%$ and $30 \%$. After pepsin treatment of adjacent sections the proportion of positively staining cells increased to between $40 \%$ and $90 \%$. This remarkable increase in the number of cells staining is shown in Fig. 1. Similar results were seen using the rabbit immunoglobulin system, though this was less sensitive in demonstrating antiglobulin activity in untreated sections. With both procedures the presence of positive staining over the intimal cells of the synovia was also noted after pepsin treatment of sections and was not a feature at this site without pepsin treatment.

Table 3 Antiglobulin activity before and after pepsin digestion with both immunofluorescence systems

\begin{tabular}{|c|c|c|c|c|c|}
\hline \multirow{3}{*}{$\begin{array}{l}\text { Patient } \\
\text { No }\end{array}$} & \multirow[t]{3}{*}{ Diagnosis } & \multicolumn{4}{|c|}{ Number of plasma cells stained } \\
\hline & & \multicolumn{2}{|c|}{ Heat aggregated $\lg G$} & \multicolumn{2}{|c|}{ Rabbit immunoglobulin } \\
\hline & & $\begin{array}{l}\text { No } \\
\text { pepsin }\end{array}$ & $\begin{array}{l}\text { With } \\
\text { pepsin }\end{array}$ & $\begin{array}{l}\text { No } \\
\text { pepsin }\end{array}$ & $\begin{array}{l}\text { With } \\
\text { pepsin }\end{array}$ \\
\hline 1 & Sero $(+)$ RA & $5-20$ & $60-80$ & 5 & $70-80$ \\
\hline 2 & Sero $(+)$ RA & $5-10$ & $70-90$ & 5 & 80 \\
\hline 3 & Sero (+) RA & $5-10$ & $50-80$ & 0 & 60 \\
\hline 4 & Sero (+) RA & $<5-15$ & $70-90$ & 5 & 80 \\
\hline 5 & Sero (t) RA & $<5-10$ & $40-80$ & 5 & $60-70$ \\
\hline 6 & Sero $(+)$ RA & $5-10$ & $60-80$ & 0 & $60-70$ \\
\hline 7 & Scro (+) RA & $5-10$ & $70-85$ & 5 & 70 \\
\hline 8 & Sero (+) RA & $<5-5$ & $70-80$ & 0 & 80 \\
\hline 9 & Scro (-) RA & $5-30$ & $50-80$ & $<5$ & $60-70$ \\
\hline $10-14+17$ & AS & 0 & 0 & 0 & 0 \\
\hline 15 & AS & $<5-5$ & $70-80$ & $<5$ & $70-80$ \\
\hline 16 & AS & $<5$ & 80 & 0 & $80-90$ \\
\hline 18 & AS & 0 & $80-90$ & $<5$ & 80 \\
\hline
\end{tabular}




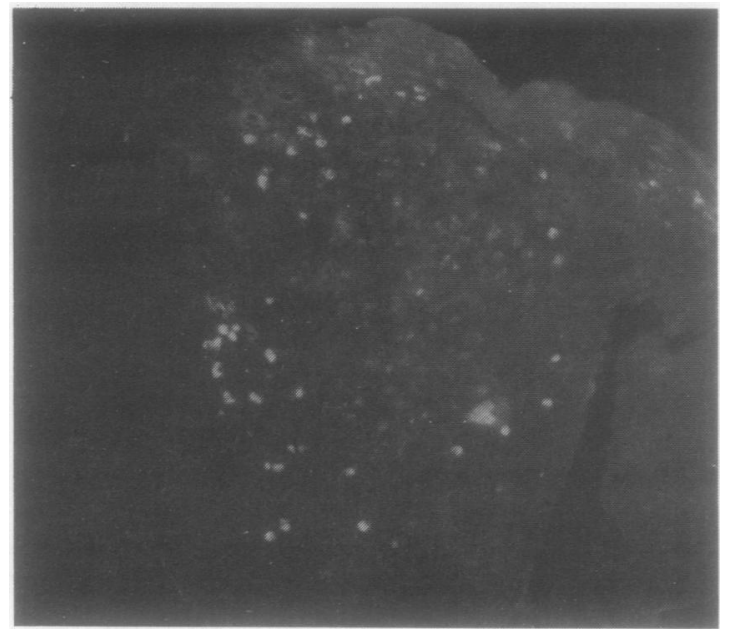

Fig. 1a

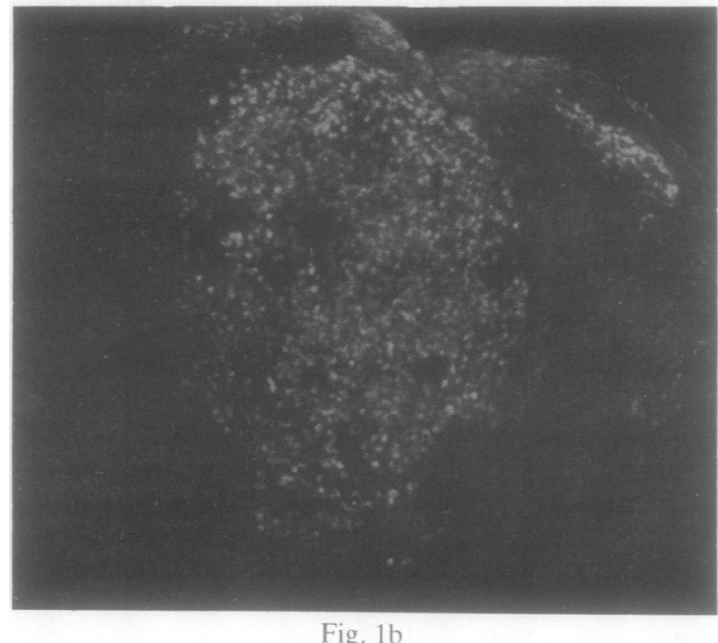

Fig. 1 Staining of rheumatoid synovium with fluorescein labelled, heat aggregated $\lg G(a)$ before and (b) after pepsin digestion.

\section{AS synovia}

Results similar to those found in the RA patients were seen in three of the nine patients with AS (Table 3). In the other six synovia no evidence of antiglobulin activity was demonstrable with either immunofluorescence technique. Intimal cell staining was again seen in the pepsin digested sections of those cases in which there was positive staining of plasma cells.

\section{Characterisation of antiglobulin activity by immunoglobulin class}

In order to ascertain the immunoglobulin class of the antiglobulin activity double staining experiments were performed on adjacent pepsin treated sections. Rhodamine labelled anti-IgG, anti-IgM, and anti$\operatorname{IgA}$ antisera were applied respectively and after washing, were followed by fluorescein labelled, heat aggregated IgG. The results are shown in Table 4. In seropositive RA cases, between $40 \%$ and $70 \%$ of the plasma cells contained IgG class rheumatoid factor. IgM antiglobulin activity was present in $5-20 \%$ of cells, while less than $10 \%$ of rheumatoid activity in plasma cells was of IgA class. The single seronegative RA case showed antiglobulin activity which was predominantly IgG. In the two AS synovia studied the antiglobulin activity was again predominantly IgG $(45-70 \%)$. IgM and IgA antiglobulin activity was present in less than $5 \%$ and from less than $5 \%$ to $20 \%$ of the total number of plasma cells respectively.

\section{Tonsillar tissues}

No staining with fluorescein labelled, heat aggregated IgG or the indirect rabbit immunoglobulin method was seen in the non-pepsin digested sections of tonsil, which therefore showed a lack of rheumatoid factor (antiglobulin) activity. In pepsin treated sections, however, $70 \%$ of plasma cells stained with both fluorescein labelled, heat aggregated $\mathrm{IgG}$ and the rabbit immunoglobulin indirect immunoog fluorescence system. This staining pattern was consistent and seen in all three specimens studied.

Myeloma marrow cells

No significant amounts of rheumatoid factor activity were identified in the serum of the IgG myeloma case using human and rabbit IgG in the ELISA system. In the $\operatorname{IgA}$ myeloma case no $\operatorname{IgA}$ or $\operatorname{IgG}$ rheumatoid factor could be detected in the serum, though a moderate amount of IgM rheumatoid factor was shown $(60 \mu \mathrm{g} / \mathrm{ml})$. In neither myeloma preparation was staining seen without pepsin digestion using either the fluorescein labelled, heat

Table 4 Immunoglobulin class of plasma cells showing antiglobulin activity

\begin{tabular}{|c|c|c|c|}
\hline \multirow[t]{2}{*}{ Diagnosis } & \multicolumn{3}{|c|}{$\begin{array}{l}\text { Plasma cells stained }(\%) \\
\text { (coincident staining) }\end{array}$} \\
\hline & $\lg G R F$ & $\operatorname{Ig} M R F$ & $\operatorname{Ig} A R F$ \\
\hline $\begin{array}{l}\text { Seropositive RA } \\
\text { (eight cases) } \\
\text { Seronegative RA }\end{array}$ & $40-70$ & $5-20$ & $<5-10$ \\
\hline $\begin{array}{l}\text { (one case) } \\
\text { Ankylosing } \\
\text { spondylitis } \\
\text { (two cases) }\end{array}$ & $45-70$ & $<5$ & $<5-20$ \\
\hline
\end{tabular}




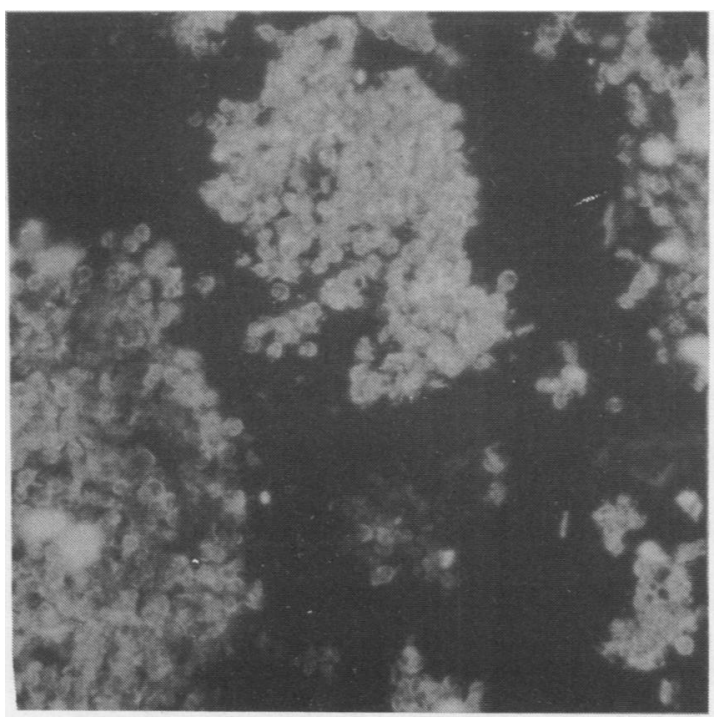

Fig. 2 Control IgA myeloma cell preparation stained with fluorescein labelled, heat aggregated $\mathrm{Ig} G$ after pepsin digestion.

aggregated human IgG or the rabbit immunoglobulin indirect immunofluorescence system. After pepsin treatment many positively staining cells were present using both systems (Fig. 2).

\section{Monoclonal tissue culture cells}

A monoclonal human B cell line was stained for rheumatoid factor activity. No staining suggesting such antiglobulin activity was seen unless the sections were pretreated with pepsin. Under such conditions of pretreatment, however, positive staining of these monoclonal B cells was seen with both systems.

\section{Discussion}

Immunofluorescence studies of the synovial membrane in RA and AS have been performed and in part confirm previous findings. The presence of IgG and IgM in synovial membrane in RA has been frequently described in the past. ${ }^{2} 5568-1116181923$ Significant numbers of plasma cells containing IgA have also been noted previously in RA, though some workers have specifically stated that $\operatorname{IgA}$ was absent from rheumatoid synovial membrane. ${ }^{8}$ is The percentages of plasma cells containing different immunoglobulin classes in RA and AS are closely similar to those found previously in this laboratory with a peroxidase-antiperoxidase technique and routinely paraffin wax embedded synovium. ${ }^{23} \mathrm{We}$ have confirmed that there is only a small proportion of plasma cells containing IgM in the synovial membrane of patients with AS.

There have been numerous previous demonstrations of the presence of rheumatoid factor in RA synovia ${ }^{2-4}$ 6-10 12-16 19 and our results confirm these findings. We have been able to show an increase in the percentage of plasma cells with antiglobulin activity after pepsin treatment of sections of RA synovia, and our results are closely similar to those reported by Munthe and Natvig. ${ }^{16}$ We have been unable, however, to reproduce the results of these workers using anti- $F\left(a b^{\prime}\right)_{2}$ and anti-Fc antisera after pepsin treatment ( $P G$ Davies, unpublished findings), and these results are of some importance since they were used to explain why enhanced staining occurred after pepsin treatment. The original method consisted in digesting the sections overnight ${ }^{16}$ but otherwise used the same conditions as we followed. Munthe and Natvig used concentrations of pepsin varying between $0.01 \mathrm{mg} / \mathrm{ml}$ and 1.00 $\mathrm{mg} / \mathrm{ml}$ and in this way a concentration of $0 \cdot 15 \mathrm{mg} / \mathrm{ml}$ was found to be the end point at which staining for $\mathrm{Fc}$, but not that for $\mathrm{F}\left(\mathrm{ab}^{\prime}\right)_{2}$ was lost. In previous unpublished work we have found that after overnight digestion with this same range of pepsin concentrations there was no remaining immunoreactivity detectable in the tissue either for $\mathrm{Fc}$ or $F\left(a b^{\prime}\right)_{2}$. This difference may be the result of improved enzyme quality in recent times. We have been unable to obtain a clear cut end point with Fc and $\mathrm{F}\left(\mathrm{ab}^{\prime}\right)_{2}$ antisera despite varying the period of digestion.

We are unaware of any previous studies in which antiglobulin activity was sought in the synovial membrane of patients with AS other than the single case that Fehr et al ${ }^{19}$ mentioned, and an absence of such activity was recorded by them. We failed to find any evidence to suggest the presence of rheumatoid factor in the first six AS synovia studied and have presented these results elsewhere. ${ }^{24} \mathrm{~A}$ further three AS synovial membranes, however, have shown different results, for although without pepsin digestion only a few plasma cells stained $(5 \%$ or less), after pepsin treatment there was a great increase in the number of cells showing rheumatoid factor activity, redolent of what had been seen with the RA synovia. Intimal cell staining was also seen and resembled that seen in RA after pepsin treatment. Staining of the synovial lining cells for antiglobulin activity was also noted by Munthe and Natvig, but they made no mention of any increase in the extensiveness of this staining after pepsin treatment of sections. ${ }^{17}$

Although early serological studies suggested the presence of $\mathrm{IgG}$ rheumatoid factor in similar 
amounts in RA and $\mathrm{AS},{ }^{25}$ this has not been borne out by subsequent work, which found the level of IgG antiglobulins to be low in AS compared with RA. ${ }^{26}$ In view of this the study of control tissues in our own investigation clearly became important. The finding of positive staining indicating rheumatoid factor activity with both fluorescein labelled, heat aggregated IgG and monomeric rabbit immunoglobulin (indirect immunofluorescence) in the pepsin treated control tissues raises considerable doubts about the specificity of this reaction. It is unlikely that Munthe and Natvig's original suggestion of pepsin cleavage showing hidden rheumatoid factor ${ }^{16}$ is correct as the two monoclonal tissue cell lines and the IgG myeloma that we studied were not producing antiglobulin, yet gave a positive staining reaction.

Our view is that this dramatic increase in the binding of heat aggregated IgG and rabbit immunoglobulin after pepsin treatment is an artefact. Recent work from this laboratory has shown that a major component of Sigma pepsin, thought to be pepsinogen, has a high affinity for immunoglobulin aggregates. ${ }^{27}$ Binding of this pepsinogen to the tissue sections in our own study may well be the explanation for the staining patterns obtained.

The authors wish to thank the Arthritis and Rheumatism Council for financial support and for an ARC Research Fellowship to one of us (PGD). We are indebted to Dr G D Johnson. Professor E J Holborow. Dr J R Archer. and Dr V Winrow for their patient assistance and provision of materials.

\section{References}

1 Kaplan M H, Vaughan J H. Reaction of rheumatoid sera with synovial tissue as revealed by fluorescent antibody studies [Abstract] Arthritis Rheum 1959: 2: 356.

2 Mellors R C. Heimer R. Corcos J. Korngold L. Cellular origin of rheumatoid factor. $J$ Exp Med 1959: 110: $875-86$.

3 Mellors R C. Nowoslowski A. Korngold L. Sengson B L. Rheumatoid factor and the pathogenesis of rheumatoid arthritis. J Exp Med 1961: 113: 475-84.

4 Mellors R C. Nowoslowski A. Korngold L. Rheumatoid arthritis and the cellular origin of rheumatoid factors. Am J Pathol 1961; 39: 533-46.

5 Kaplan M H. The site of formation of rheumatoid factor. Arthritis Rheum 1963: 6: 475-80.

6 McCormick J N. An immunofluorescence study of rheumatoid factor. Ann Rheum Dis 1963: 22: 1-10.

7 Ball J. Bahgat N. Taylor G. Effect on aldehyde fixation of cellular rheumatoid factor and certain tissuc antigens. J Histochem Cytochem 1964: 12: 737-9.

8 Fish A J. Michacl A F. Gewurz H. Good R A. Immunopathologic changes in rheumatoid arthritis synovium. Arthritis Rheum 1966: 9: $267-80$.

9 Rodnan W S. Williams R C. Bilka P J. Muller-Eberhard H J. Immunofluorescent localisation of the third and fourth compo- nent of complement in synovial tissue from patients with rheumatoid arthritis. J Lab Clin Med 1967: 69: 141-50.

10 Nowoslowski A. Brzosko W J. Immunopathology of rheumatoid arthritis. I. The rheumatoid synovitis. Pathol Eur 1967: 2: 198-219.

11 Brandt K D. Cathcart E S. Cohen A S. Studies of immune deposits in synovial membranes and corresponding synovial fluids. J Lab Clin Med 1968: 72: 631-47.

12 Bonomo L. Tursi A. Gillardi U. Distribution of the anti-gamma globulin factors in the synovial membrane and other tissues in various diseases. Ann Rheum Dis 1968: 27: 122-9.

13 Friis J. Immunohistochemical demonstration of rheumatoid factor (RF) in alcohol-fixed synovial tissue from patients with rheumatoid arthritis (RA). Acta Pathol Microbiol Scand 1969: 75: $71-84$

14 Bonomo L. Tursi A, Trizio D, Gillardi U, Dammacco F. Immune complexes in rheumatoid synovitis: a mixed staining immunofluorescence study. Immunology 1970: 18: 557-63.

15 Tursi A. Trizio D. Bonomo L. An immunofluoresence mixed staining technique for the detection of IgG-rheumatoid factor and IgG-B1c complexes in tissues. Clin Exp Immunol 1970; 6: 767-72.

16 Munthe E. Natvig J B. Immunoglobulin classes, subclasses and complexes of IgG rheumatoid factor in rheumatoid plasma cells. Clin Exp Immunol 1972: 12: 55-70).

17 Munthe E. Natvig J B. Complement fixing intracellular complexes of $\operatorname{lgG}$ rheumatoid factor in rhcumatoid plasma cells. Scand J limmunol 1972: 1: 217-29.

18 Mesteck! J. Miller E J. Presence of antibodics specific to cartilage-type collagen in rhcumatoid synovial tissue. (lin Exp Immunol 1975: 22: 453-6.

19 Fchr K. Velvart M. Rauber M. et al. Production of agglutinio tors and rheumatoid factors in plasma cells of rheumatoid ane non-rheumatoid svnovial tissues. Arthritis Rheum 1981: 24 $510-9$.

20 March R E. Rechack J S. Holborow E J. Jones V E. Jakoby $R$ $K$. The complement fixing properties and class distribution of rhcumatoid factors (antiglobulins) in rheumatoid arthritis and other discases. (lin Exp Immunol 1982: 48: 555-60).

21 Sainte-Maric (j. A paraffin embedding technique for studies emploving immunofluorescence. J Histochem citoche'm 1962: 10: 25116 .

22 Johnson G D. Holborow E J. Dorling J. Immunofluoresence and immunoenzyme techniques. In: Weir D M. ed. Handbook of experimental immunology. Oxford: Blackwell Scientific, 1978: ch 15.

23 Revell P A. Mayston V. Histopathology of the synovial membrane of peripheral joints in ankylosing spondylitis. Ann Rhe'um Dis 1982: 41: 579-86.

24 Davies P G. Revell P A. Mayston V. Johnson G D. Holborow E J. Immunofluoresence studies of rheumatoid factor in rhcumatoid arthritis (RA) and ankylosing spondylitis (AS) synovial membrane |Abstract|. Ann Rheum Dis 1983: 42: 220.

25 Howell F A. Chamberlain M A. Perry R A. Torrigiani G. Roit I M. IgG antiglobulin levels in patients with psoriatic arthropathy, ankylosing spondylitis and gout. Ann Rheum Dis 1972: 31: i29-31.

26 Allen C. Elson C J. Scott D G I. Bacon P A. Bucknall R C. IgG of antiglobulins in rheumatoid arthritis and other arthritides: N relationship with clinical features and other parameters. Ann Rheum Dis 1981: 40: 127-31.

27 Kirk A P. O'Hara B P. McMahon M S, Archer J R. Currey H L F. Pepsinogen-an immunoglobulin binding artefact in "collagen preparation. Proceedings of the second annual general meeting of the British Society for Rheumatology. 1985. 